\title{
Pengaruh Penempatan Karyawan Dan Pengembangan Karir Terhadap Kepuasan Kerja Melalui Motivasi Kerja Karyawan Sebagai Variabel Intervening Pada PT. Astra International Tbk, Auto 2000 Bypass Padang
}

\author{
Della Asmaria Putri, Yulyana Sapitri, Zefriyenni \\ Universitas Putra Indonesia YPTK Padang, Indonesia \\ yulianasafitri290799@gmail.com
}

\begin{abstract}
ABSTRAK
Rendahnya kepuasan kerja diduga disebabkan oleh penempatan karyawan, pengembangan karir dan kurangnya pemberian motivasi terhadap karyawan pada PT. Astra International Tbk, Auto 2000 Bypass Padang, maka Penelitian ini bertujuan untuk mengetahui pengaruh penempatan karyawan dan pengembangan karir terhadap kepuasan kerja melalui motivasi kerja pada PT. Astra International Tbk, Auto 2000 Bypass Padang. Metode pengumpulan data melalui survey dan penyebaran kuesioner, dengan sampel 85 responden. Metode analisis yang digunakan dalam penelitian ini adalah dengan menggunakan analisis regresi linear berganda dan analisis jalur (Path Analysis). Hasil penelitian yang didapatkan: (a) Terdapat pengaruh positif dan signifikan penempatan karyawan, pengembangan karir terhadap motivasi kerja dibuktikan dengan nilai $t$ hitung $>t$ tabel $(2,195>1,989)$ dan $(5,817>1,989)$. (b) Terdapat pengaruh tidak signifikan penempatan karyawan dan pengembangan karir terhadap kepuasan kerja, dibuktikan dengan nilai t hitung < t tabel $(1,421<1,989)$ dan $(-$ $2,444<1,989)$. (c) Terdapat pengaruh positif dan signifikan motivasi kerja terhadap kepuasan kerja, dibuktikan dengan nilai t hitung $>\mathrm{t}$ tabel $(6,680>1,989)$. (d) penempatan karyawan dan pengembangan karir berpengaruh positif dan signifikan secara tidak langsung terhadap kepuasan kerja melalui motivasi kerja karyawan sebagai variabel intervening dibuktikan dengan nilai Inderect effect > direct effect atau 0,174>0,158 dan 0,462 > ($0,313)$.
\end{abstract}

Kata kunci : Penempatan Karyawan, Pengembangan Karir, Motivasi Kerja Karyawan, Kepuasan Kerja.

\section{PENDAhuluan}

Memasuki era globalisasi, kebutuhan akan sumber daya manusia yang unggul tidak dapat dipungkiri dalam menghadapi persaingan global dan perubahan kondisi saat ini sehingga membuat banyak perusahaan mengubah cara pandang mereka terhadap karyawan. Dalam suatu organisasi tentu terdapat suatu tujuan yang ingin dicapai salah satu faktor yang mendukung dalam pencapaian tujuan tersebut adalah individu-individu atau sumber daya manusia di dalam organisasi itu sendiri. Manajemen sumber daya manusia menganggap bahwa karyawan adalah kekayaan (asset) utama organisasi yang harus dikelola dengan baik, jadi MSDM sifatnya lebih strategis bagi organisasi dalam mencapai tujuan-tujuan yang telah ditetapkan. Untuk mencapai tujuan, suatu organisasi tentu mengharapkan produktivitas dari karyawannya. Produktivitas kerja dipandang sebagai kemampuan karyawan untuk mencapai hasil yang diinginkan, dalam mencapai hasil yang diinginkan tentu dibutuhkan kepuasan kerja yang positif dari karyawan.

Ada beberapa hal penting yang dapat mempengaruhi tingkat kepuasan kerja seorang karyawan pada suatu perusahaan, diantaranya untuk meningkatkan kepuasan kerja adalah penempatan karyawan, memberikannya pengembangan karir dan melalui motivasi.

Pertama untuk memicu peningkatan kepuasan kerja karyawan adalah dengan memberikan penempatan, penempatan karyawan adalah Menurut (Wahyuni \& Pase, 2019) penempatan karyawan berarti mengalokasikan para karyawan pada posisi kerja tertentu, hal ini khusus terjadi pada karyawan baru. Kepada para karyawan lama yang telah menduduki jabatan atau pekerjaan termasuk sasaran fungsi penempatan dalam arti mempertahankan posisinya atau memindahkan pada posisi lain.

Kedua pengembangan karir merupakan Menurut (Hasibuan, 2019) pengembangan karir merupakan suatu proses dalam peningkatan dan penambahan kemampuan seseorang karyawan yang dilakukan secara formal dan berkelanjutan untuk mencapai sasaran dan tujuan kariernya. 
Ketiga motivasi kerja merupakan Menurut (Diansyah \& Saepul, 2017) motivasi kerja merupakan suatu perangsang keinginan dan daya penggerak kemauan bekerja seseorang karena setiap motivasi mempunyai tujuan tertentu yang ingin dicapai. motivasi sering kali disamakan dengan dorongan, dorongan atau tenaga tersebut merupakan gerak jiwa dan jasmani untuk berbuat, sehingga motivasi tersebut merupakan suatu hal yang menggerakkan manusia untuk bertingkah laku dan perbuatan itu mempunyai tujuan tertentu.

PT. Astra International Tbk, Auto 2000 Bypass Padang merupakan perusahaan swasta nasional yang berfungsi sebagai dealer kendaraan merk Toyota, yang berdiri pada tanggal 20 Februari 1957 yang memusatkan kantor pusatnya di Jakarta, dan mendirikan perusahaan di kota padang sebagai salah satu cabangnya.

Permasalahan yang terkait dengan kepuasan kerja karyawan pada PT. Astra International Tbk, Auto 2000 Bypass Padang yaitu tingkat angka turnover yang tergolong cukup tinggi.

Berikut adalah Tingkat turnover karyawan Auto 2000 Bypass Padang pada tahun 2016-2020, yang diformulasikan berdasarkan tabel berikut :

Tabel 1

Data Rata-rata Turnover Karyawan Auto 2000 Bypass Padang Tahun 2016-2020

\begin{tabular}{|l|l|l|l|l|l|l|l|l|l|l|l|l|l|l|l|l|}
\hline Bulan & \multicolumn{3}{|c|}{2016} & \multicolumn{4}{|c|}{2017} & \multicolumn{3}{|c|}{2018} & \multicolumn{3}{|c|}{2020} \\
\hline & out & msk & jml & out & msk & jml & out & msk & jml & out & msk & jml & out & msk & jml \\
\hline Jan & 1 & - & 1 & - & - & - & - & - & - & 2 & - & 2 & - & - & - \\
\hline Feb & - & - & - & - & - & - & 1 & - & 1 & - & - & - & - & 1 & 1 \\
\hline Mar & - & - & - & - & - & - & - & - & - & - & 1 & 1 & - & - & - \\
\hline Apr & - & - & - & - & - & - & - & 1 & 1 & - & - & - & 2 & - & 2 \\
\hline Mei & - & - & - & - & - & - & - & - & - & 1 & - & 1 & - & - & - \\
\hline Jun & - & - & - & - & 3 & 3 & - & - & - & - & - & - & 1 & - & 1 \\
\hline Juli & - & - & - & - & - & - & 1 & - & 1 & - & 1 & 1 & - & - & - \\
\hline Agust & 1 & - & 1 & - & - & - & - & - & - & - & - & - & 4 & - & 4 \\
\hline Sept & - & - & - & - & - & & 2 & - & 2 & 1 & - & 1 & - & - & - \\
\hline Okt & - & - & - & - & 1 & 1 & - & - & - & - & - & & - & - & - \\
\hline Nov & - & - & - & - & - & - & - & - & - & 2 & - & 2 & 2 & - & 2 \\
\hline Des & - & - & - & - & - & - & - & 1 & 1 & - & - & - & - & - & - \\
\hline Total & & & 2 & & & 4 & & & 6 & & & 8 & & \\
\hline
\end{tabular}

Sumber : PT. Astra International Tbk, Auto 2000 Bypass Padang

Berdasarkan tabel 1.1 diatas, dapat dilihat bahwa sejak tahun 2016 pada bulan Januari sampai dengan November 2020, angka turnover karyawan Auto 2000 Bypass Padang tergolong cukup tinggi. Pada tahun 2020 mengalami peningkatan pesat dari tahun 2019 berjumlah 10 orang karyawan. Khususnya pada bulan Agustus 2020 karyawan yang keluar dari perusahaan mencapai 4 orang karyawan, dan terhitung dari Januari 2016 sampai dengan November 2020, karyawan Auto 2000 Bypass Padang mengalami kenaikan tingkat turnover hingga mencapai 30 orang karyawan dari keseluruhan jumlah karyawan.

Dari keterangan data diatas dapat disimpulkan bahwa tingkat kepuasan kerja karyawan belum optimal, ini didasari atau disebabkan oleh penempatan karyawan, pengembangan karir yang kurang sesuai dengan keahliannya dan pemberian motivasi kerja terhadap karyawan yang kurang maksimal sehingga dapat mempengaruhi penurunan pencapaian kepuasan karyawan dalam bekerja.

\section{TINJAUAN PUSTAKA}

\subsection{Kepuasan Kerja}

Menurut (Mangkunegara, 2017) kepuasan kerja merupakan sikap (positif) tenaga kerja terhadap pekerjaannya, yang timbul berdasarkan penilaian terhadap situasi kerja. Karyawan yang puas lebih menyukai situasi kerjanya dari pada karyawan yang tidak puas sehingga kinerjanya akan maksimal. 


\subsection{Penempatan Karyawan}

Menurut (Lukiyana, 2017) penempatan karyawan adalah penempatan yang berkaitan dengan pencocokan seseorang dengan jabatan yang akan dipegangnya berdasarkan pada kebutuhan jabatan dan pengetahuan, ketrampilan, kemampuan dan kepribadian karyawan serta mengalokasikan para karyawan pada posisi pekerjaan tertentu, hal ini khusus terjadi pada karyawan baru.

\subsection{Pengembangan Karir}

Menurut (Hasibuan, 2019) pengembangan karir merupakan satu proses untuk meningkatkan kemampuan seorang karyawan baik dilakukan secara individu maupun secara organisasi yang mempunyai tujuan sampai puncak karir yang diinginkannya. Dengan demikian dengan melakukan pengembangan karir maka dapat membantu suatu aktifitas kepegawaiannya dalam merencanakan karir mereka dimasa depan, agar perusahaan dan karyawan yang bersangkutan dapat mengembangkan diri secara maksimum.

\subsection{Motivasi Kerja}

Menurut (Diansyah \& Saepul, 2017) motivasi kerja merupakan suatu perangsang keinginan dan daya penggerak kemauan bekerja seseorang karena setiap motivasi mempunyai tujuan tertentu yang ingin dicapai. motivasi sering kali disamakan dengan dorongan, dorongan atau tenaga tersebut merupakan gerak jiwa dan jasmani untuk berbuat, sehingga motivasi tersebut merupakan suatu driving force yang menggerakkan manusia untuk bertingkah laku dan perbuatan itu mempunyai tujuan tertentu.

Berdasarkan telaah pustaka yang dilakukan diatas, maka model pemikiran teoritis yang dikembangkan pada penelitian ini terlihat pada gambar sebagai berikut :

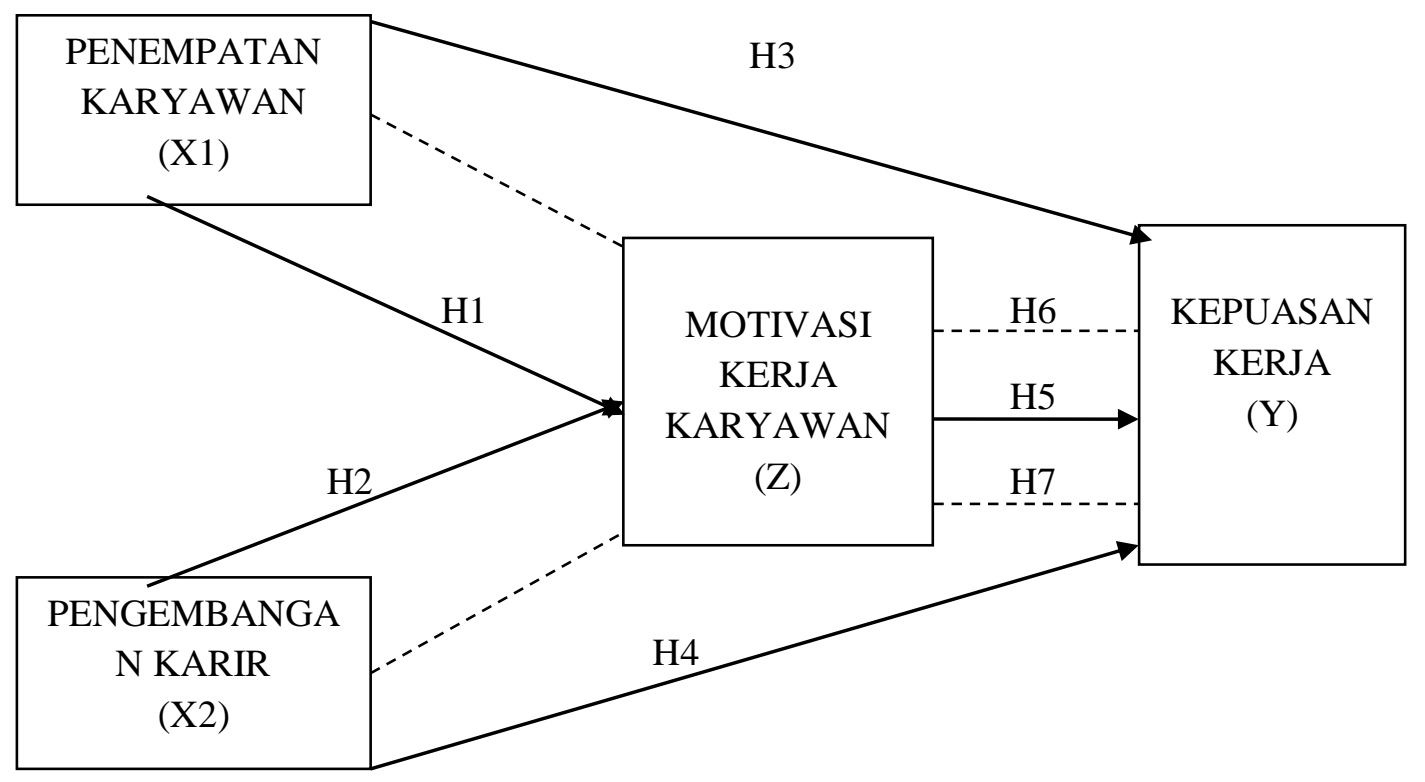

\section{Gambar 1. Kerangka pikir penelitian}

\section{METODEOLOGI PENELITIAN}

\subsection{Objek Penelitian}

Tempat penelitian ini dilakukan di PT. Astra International Tbk, Auto 2000 Bypass Padang yang beralamat di Jl. Bypass Padang Km 12, Sungai Sapih, Kec. Kuranji, Kota Padang, Sumatra Barat. Tepl (0751) 498800, Fax (0751) 496464. Merupakan salah satu kantor yang memberikan data dan informasi yang diperlukan guna mendukung penulisan penelitian ini.

\subsection{Populasi dan Sampel}

Dalam penelitian ini yang menjadi populasi adalah seluruh karyawan PT. Astra International Tbk, Auto 2000 Bypass Padang sebanyak 547 orang karyawan. Sedangkan pemilihan sampel untuk penelitian ini dilakukan dengan probability sampling yaitu populasi yang dijadikan sampel adalah populasi yang memenuhi kriteria tertentu dengan tujuan agar sampel yang diambil bisa lebih reprehensif dengan kriteria yang telah ditentukan. Untuk menentukan besarnya sampel digunakan 
rumus Slovin, sehingga diperoleh sebanyak 85 orang responden yang dapat mewakili dari populasi sebanyak 547 orang karyawan.

\subsection{Teknik Pengujian Instrumen}

\subsubsection{Uji Validitas}

Menurut (Sutrisno, 2019) menyatakan bahwa uji validitas digunakan untuk mengukur sah atau tidaknya suatu kuesioner. Suatu pengukuran dikatakan valid jika pernyataan pada kuesioner mampu untuk mengungkapkan nilai variabel yang akan diteliti. Untuk mengukur validitas, digunakan teknik correlation product moment dengan mengkorelasikan skor butir dengan skor total.

\subsubsection{Uji Reliabilitas}

Uji reliabilitas merupakan suatu pengukuran yang menunjukan stabilitas dan konsisten dari suatu instrumen yang mengukur suatu fenomena (variabel). Alat ukur untuk mengukur reliabilitas adalah Cronbach Alpha. Suatu variabel dikatakan reliabel, apabila hasil $a>0,5=$ reliabel dan jika hasil $a<0,5=$ tidak reliabel. Semakin tinggi koefisien reliabilitas semakin reliable jawaban yang diperoleh dari responden (Siagian, 2018).

\subsection{Uji Asumsi Klasik}

\subsubsection{Uji Normalitas}

Uji normalitas bertujuan untuk menguji apakah dalam sebuah model regresi, variabel pengganggu dan residual atau variabel dependen dan variabel independen memiliki distribusi hipotesis normal atau tidak.

\subsubsection{Uji Multikolinearitas}

Uji multikolonieritas bertujuan untuk menguji apakah model regresi ditemukan adanya korelasi antar variabel independen. Model regresi yang baik seharusnya tidak terjadi korelasi di antara variabel independen.

\subsubsection{Uji Heteroskedastisitas}

Uji Heteroskedastisitas adalah alat uji yang dilakukan untuk menguji atau melihat apakah dalam model regresi terjadi ketidaksamaan variabel dari residual suatu pengamatan ke pengamatan lain.

\subsection{Analisis Regresi Linear Berganda}

Analisis regresi linear berganda yaitu sebuah teknik analis data yang digunakan untuk memprediksi nilai variabel terikat kepuasan kerja (Y) dan motivasi kerja karyawan (Z) karena pengaruh variabel bebas penempatan karyawan (X1) serta pengembangan karir (X2).

Rumus :

Model Regresi I: $\mathrm{Z}=a+b_{1} X_{1}+b_{2} X_{2}+e$

Model Regresi II: $\mathrm{Y}=a+b_{3} X_{1}+b_{4} X_{2}+b_{5} Z+e$

\subsection{Analisis Jalur (Path Analysis)}

Analisis jalur merupakan perluasan analisis regresi linear berganda atau analisis jalur adalah penggunaan regresi untuk menaksir hubungan kausalitas antar variabel (model causal) yang telah ditetapkan sebelumnya berdasarkan teori. Teknik analisis jalur mengambarkan keterkaitan regresi berganda dengan variabel yang hendak diukur.

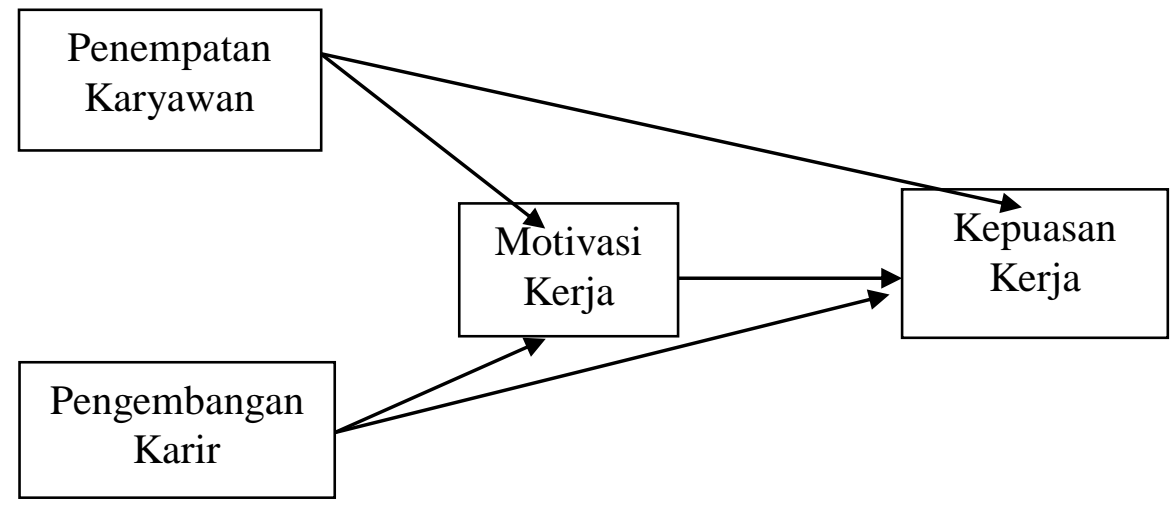

Gambar 2.Diagram Jalur Pengaruh Penempatan Karyawan dan Pengembangan Karir Terhadap Kepuasan Kerja Melalui Motivasi Kerja Karyawan 


\subsection{Uji Hipotesis}

\subsubsection{Uji t}

Uji $\mathrm{t}$ untuk membuktikan ada atau tidaknya pengaruh penempatan karyawan dan pengembangan karir terhadap kepuasan kerja melalui motivasi kerja karyawan sebagai variabel intervening.

3.7.2 Uji F

Uji statistik yang digunakan untuk membuktikan pengaruh independen dan terhadap variabel dependen secara bersama-sama.

\subsubsection{Uji Koefisien Determinasi}

Uji koefisien determinasi bertujuan untuk melihat seberapa besar proporsi variabel independen secara bersama-sama mempengaruhi variabel dependen.

\section{HASIL PENELITIAN DAN PEMBAHASAN}

\subsection{Uji Asumsi Klasik}

\subsubsection{Uji Normalitas}

Uji normalitas bertujuan untuk menguji apakah dalam model regresi, variabel penganggu atau residual normal dan tidak normal. Hal ini penting karena dalam uji regresi semua mengasumsikan nilai residual telah terdistribusi normal. Uji normalitas yang umum dipakai adalah p-plot. Pada normal pplot prinsipnya normalitas dapat dideteksi dengan melihat penyebaran data (titik) pada sumbu diagonal grafik atau melihat histogram dari residuaknya.

Hasil uji normalitas dalam penelitian ini adalah sebagai berikut:

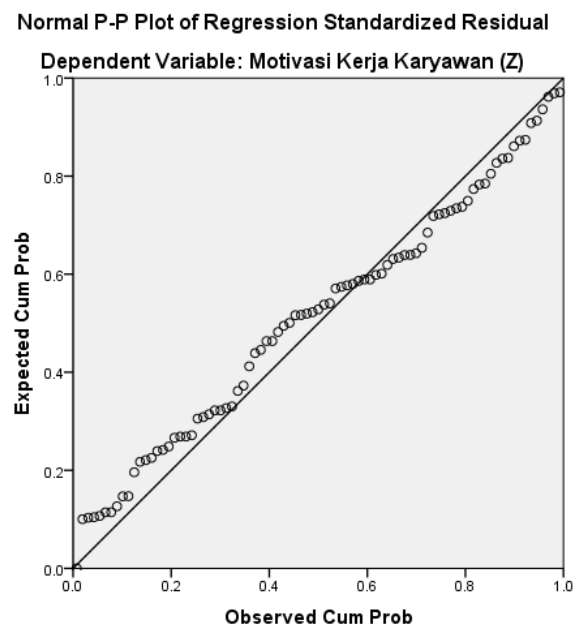

Sumber : Data lampiran diolah dengan SPSS versi 21

Gambar 3Uji NormalitasNormal Probability Plot (Model Regresi I)

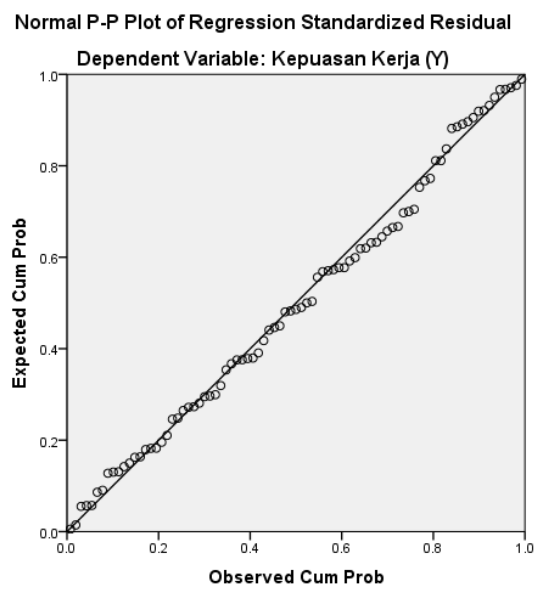

Sumber : Data lampiran diolah dengan SPSS versi 21

Gambar 4 Uji Normalitas Normal Probability Plot (Model Regresi II) 
Dari data kurva diatas dapat dilihat bahwa data menyebar disekitar diagram dan mengikuti model regresi sehingga dapat disimpulkan bahwa data yang diolah merupakan data yang berdistribusi normal sehingga uji normalitas terpenuhi.

\subsubsection{Uji Multikolinearitas}

Uji mutikolinearitas digunakan untuk menguji apakah model regresi ditemukan adanya korelasi antar variabel bebas. Model regresi yang baik seharusnya tidak terjadi korelasi diantara variabel bebas. Uji ini dilakukan dengan menghitung nilai Variance Inflation Factor (VIF) dari masing-masing variabel independen. Nilai yang umum dipakai untuk menunjukkan tidak adanya multikolinearitas adalah nilai VIF $<10$. Pada penelitian ini menunjukkan hasil sebagai berikut :

Tabel 4.19

Uji Multikolinearitas Tolerance dan VIF

\begin{tabular}{|l|c|c|c|c|}
\hline \multirow{2}{*}{ Model } & \multicolumn{2}{|c|}{ Persamaan 1 } & \multicolumn{2}{c|}{ Persamaan 2 } \\
\cline { 2 - 5 } & Tolerance & VIF & Tolerance & VIF \\
\hline Penempatan Karyawan & 0,548 & 1,824 & 0,518 & 1,931 \\
\hline Pengembangan Karir & 0,548 & 1,824 & 0,388 & 2,576 \\
\hline Motivasi Kerja & & & 0,446 & 2,241 \\
\hline
\end{tabular}

Sumber : Data lampiran diolah dengan SPSS versi 21

Berdasarkan tabel 4.19 diketahui bahwa nilai tolerance semua variabel independen $>0,10$. Nilai Variance Inflation Factor $(V I F)<10$. Pada persamaan I Penempatan karyawan dan Pengembangan karir memiliki nilai Tolerance sebesar 0,548 dan nilai VIF sebesar 1,824, dan Pada persamaan II penempatan karyawan memiliki nilai Tolerance sebesar 0,518 dan VIF sebesar 1,931. Kemuadian Pengembangan karir memiliki nilai Tolerance sebesar 0,388 dan nilai VIF sebesar2,576. Sedangkan Motivasi kerja memiliki nilai Tolerance sebesar 0,446 dan VIF sebesar 2,241. Maka dapat disimpulkan bahwa model regresi dalam penelitian ini tidak terjadi multikolinearitas.

\subsubsection{Uji Heteroskedastisitas}

Uji heteroskedastisitas bertujuan menguji apakah dalam model regresi terjadi ketidaksamaan variance dari residu satu pengamatan ke pengamatan lainnya. penelitian ini dapat dilihat dari hasil output pola gambar scatterplot pada model regresi berikut :

Scatterplot

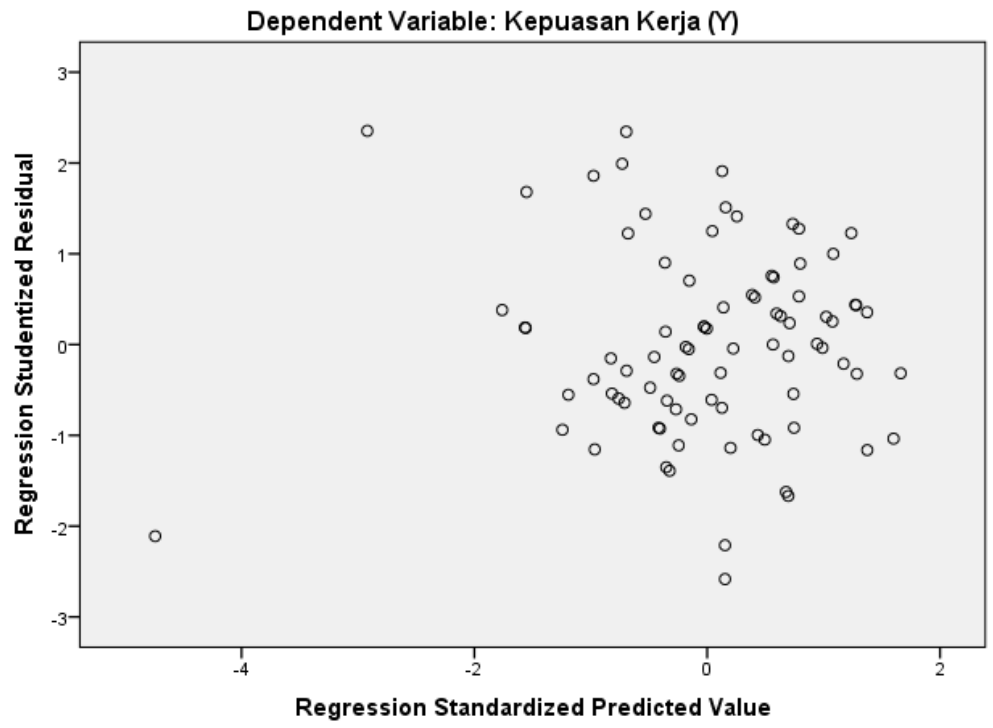

Sumber : Data lampiran diolah dengan SPSS versi 21 Gambar 5 Scatterplot 
Berdasarkan gambar 4.4 diatas dapat diketahui bahwa tidak terjadi heteroskedastisitas pada model regresi, sebab tidak ada pola yang jelas menunjukkan bahwa titik-titik data menyebar diatas dan dibawah angka 0 pada sumbu Y. Sehingga dapat disimpulkan bahwa dalam penelitian ini tidak terjadi heteroskedastisitas.

\subsection{Analisis Regresi Linear Berganda}

\subsubsection{Model 1}

Untuk mengetahui pengaruh Penempatan Karyawan dan Pengembangan Karir terhadap Motivasi Kerja Karyawan maka digunakan analisis regresi linear berganda. berikut uji regresi yang dilakukan pada tabel sebagai berikut :

\section{Tabel 4.20}

Hasil Uji Regresi Pengaruh Penempatan Karyawan (X1) dan Pengembangan Karir (X2) terhadap Motivasi Kerja Karyawan $(Z)$

\section{Coefficients $^{\mathbf{a}}$}

\begin{tabular}{|c|c|c|c|c|c|c|}
\hline \multirow{2}{*}{\multicolumn{2}{|c|}{ Model }} & \multicolumn{2}{|c|}{$\begin{array}{c}\text { Unstandardized } \\
\text { Coefficients }\end{array}$} & \multirow{2}{*}{$\begin{array}{l}\text { Standardized } \\
\text { Coefficients } \\
\text { Beta }\end{array}$} & \multirow[t]{2}{*}{$\mathrm{t}$} & \multirow[t]{2}{*}{ Sig. } \\
\hline & & $\mathrm{B}$ & Std. Error & & & \\
\hline \multirow{3}{*}{1} & (Constant) & 12.084 & 3.298 & & 3.664 & .000 \\
\hline & $\begin{array}{l}\text { Penempatan Karyawan } \\
\text { (X1) }\end{array}$ & .208 & .095 & 219 & 2.195 & .031 \\
\hline & $\begin{array}{l}\text { Pengembangan Karir } \\
\text { (X2) }\end{array}$ & .521 & .090 & .579 & 5.817 & .000 \\
\hline
\end{tabular}

a. Dependent Variable: Motivasi Kerja Karyawan (Z)

Sumber : Data lampiran diolah dengan SPSS versi 21

Berdasarkan tabel diatas maka dapat dilihat persamaan regresinya yaitu sebagai berikut :

$$
\mathrm{Z}=12,084+0,208 \mathrm{X} 1+0,521 \mathrm{X} 2+\mathrm{e}
$$

Persamaan regresi tersebut menunjukkan bahwa :

1. Nilai konstanta menunjukkan sebesar 12,084 , artinya apabila nilai penempatan karyawan (X1) dan pengembangan karir (X2) tetap, maka motivasi kerja karyawan (Z) nilainya adalah sebesar 12,084.

2. Setiap terjadi kenaikan penempatan karyawan akan diikuti kenaikan motivasi kerja 0,208 apabila variabel lain diasumsikan tetap.

3. Setiap terjadi kenaikan pengembangan karir akan diikuti kenaikan motivasi kerja karyawan 0,521 apabila variabel lain diasumsikan tetap.

4. $\mathrm{e}_{1}$ merupakan variabel motivasi kerja karyawan yang tidak dijelaskan oleh penempatan karyawan dan pengembangan karir. Besarnya $\mathrm{e}_{1}=\sqrt{\left(1-R^{2}\right)}=\sqrt{(1-0.554)}=0.446$. Nilai $\mathrm{R}^{2}$ didapat dari uji koefisien determinasi antara penempatan karyawan dan pengembangan karir melalui motivasi kerja karyawan.

\subsubsection{Model II}

Untuk mengetahui pengaruh penempatan karyawan dan pengembangan karir terhadap kepuasan kerja melalui motivasi kerja karyawan maka digunakan analisis regresi linear berganda. berikut uji regresi yang dilakukan pada tabel sebagai berikut : 
Tabel 4.21

Hasil Uji Regresi Pengaruh Penempatan Karyawan (X1), Pengembangan Krir (X2) dan Motivasi Kerja Karyawan (Z) Terhadap Kepuasan Kerja (Y) Coefficients $^{\mathrm{a}}$

\begin{tabular}{|c|c|c|c|c|c|c|}
\hline \multirow[t]{2}{*}{ Mod } & & \multicolumn{2}{|c|}{$\begin{array}{l}\text { Unstandardized } \\
\text { Coefficients }\end{array}$} & \multirow{2}{*}{$\begin{array}{c}\begin{array}{c}\text { Standardized } \\
\text { Coefficients }\end{array} \\
\text { Beta }\end{array}$} & \multirow[t]{2}{*}{$\mathrm{t}$} & \multirow[t]{2}{*}{ Sig. } \\
\hline & & $\mathrm{B}$ & Std. Error & & & \\
\hline \multirow{4}{*}{1} & (Constant) & 16.231 & 3.582 & & 4.531 & .000 \\
\hline & $\begin{array}{l}\text { Penempatan Karyawan } \\
\text { (X1) }\end{array}$ & .139 & .098 & .158 & 1.421 & .159 \\
\hline & Pengembangan Karir (X2) & -.262 & .107 & -.313 & -2.444 & .017 \\
\hline & $\begin{array}{l}\text { Motivasi Kerja Karyawan } \\
\text { (Z) }\end{array}$ & .743 & .111 & .798 & 6.680 & .000 \\
\hline
\end{tabular}

a. Dependent Variable: Kepuasan Kerja (Y)

Sumber : Data lampiran diolah dengan SPSS versi 21

Berdasarkan tabel diatas dapat diketahui persamaan regresinya sebagai berikut:

$$
\mathrm{Y}=16,231+0,139 \mathrm{X} 1-0,262 \mathrm{X} 2+0,743 \mathrm{Z}+\mathrm{e}
$$

Dari persamaan tersebut dapat diambil kesimpulan bahwa:

1. Nilai konstanta menunjukkan sebesar 16,231 artinya jika penempatan karyawan (X1), pengembangan karir (X2) dan motivasi kerja karyawan (Z) bernilai tetap maka kepuasan kerja (Y) bernilai sebesar 16,231.

2. Setiap terjadi kenaikan penempatan karyawan 0,139 akan diikuti kenaikan kepuasan kerja, apabila variabel lain diasumsikan tetap.

3. Setiap terjadi penurunan pengembangan karir $-0,262$ akan diikuti penurunan kepuasan kerja apabila variabel lain diasumsikan tetap.

4. Setiap terjadi kenaikan motivasi kerja karyawan 0,743 akan diikuti kenaikan kepuasan kerja, apabila variabel lain diasumsikan tetap.

5. $\mathrm{e}_{1}$ merupakan variabel kepuasan kerja yang tidak dijelaskan oleh penempatan karyawan, pengembangan karir dan motivasi kerja karyawan. Besarnya $\mathrm{e}_{1}=\sqrt{\left(1-R^{2}\right)}=$ $\sqrt{(1-0,484)}=0,516$. Nilai $R^{2}$ didapat dari uji koefisien determinasi antara penempatan karyawan, pengembangan karir dan motivasi kerja karyawan terhadap kepuasan kerja.

\subsection{Analisis jalur (Path Analysis)}

\subsubsection{Koefisien Jalur Model I}

Berdasarkan persamaan yang didapat dari analisis regresi linear berganda pada model I maka dapat dirumuskan diagram jalur model I sebagai berikut :

$$
\mathrm{Z}=0,219 \mathrm{X} 1+0,579 \mathrm{X} 2+\mathrm{e}
$$

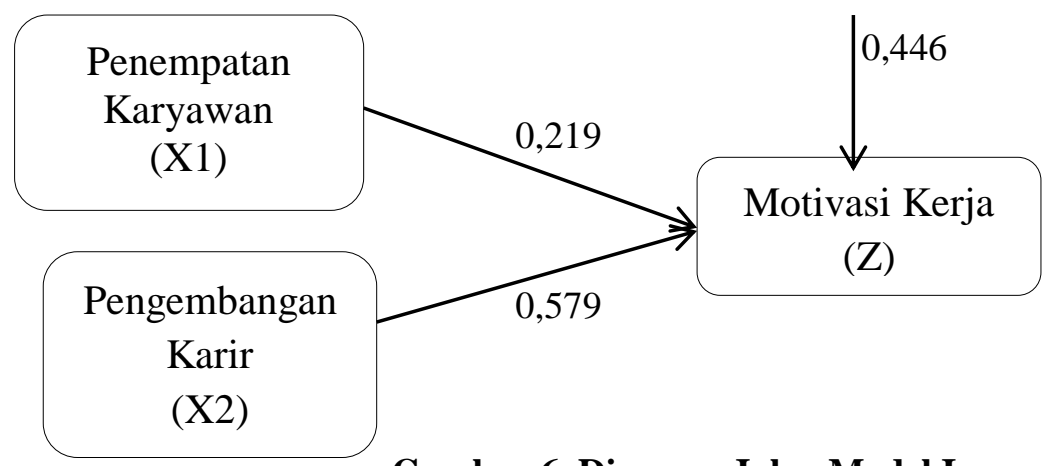

Gambar 6. Diagram Jalur Model I 


$$
\begin{aligned}
* \mathrm{e}_{1} & =\sqrt{\left(1-R^{2}\right)} \\
& =\sqrt{(1-0,554)} \\
& =0,446 .
\end{aligned}
$$

\subsubsection{Koefisien Jalur Model II}

Berdasarkan persamaan yang didapat dari analisis regresi linear berganda pada model II maka dapat dirumuskan diagram jalur sebagai berikut :

$$
\mathrm{Y}=0,158 \mathrm{X} 1-0,313 \mathrm{X} 2+0,798 \mathrm{Z}+\mathrm{e}
$$

\section{Gambar 4.6}

Diagram jalur Model II

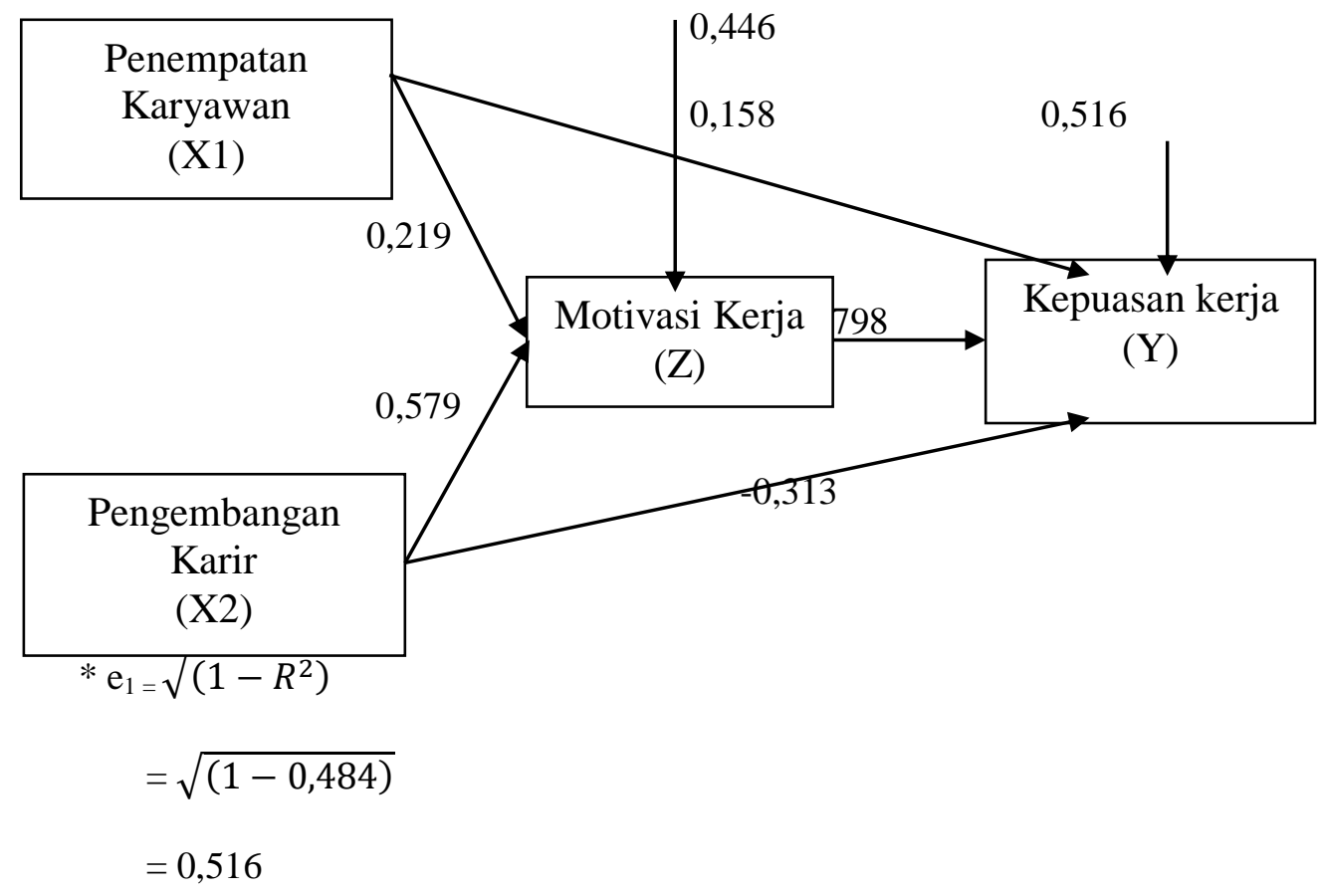

\subsection{Uji Hipotesis}

\subsubsection{Uji t}

1. Model Regresi I

Derajat kebebasan (df) n-k-1 yaitu 85-2-1 = 82 ( $\mathrm{n}$ merupakan responden dan k merupakan jumlah variabel independen), sehingga hasil yang diperoleh untuk $t_{\text {tabel }}$ sebesar 1,989. Dari hasil olah data dapat disajikan pada tabel berikut ini :

Tabel 4.22

Uji Parsial Variabel Penempatan Karyawan (X1) dan Pengembangan Karir (X2) Terhadap Motivasi Kerja (Z)

\begin{tabular}{|l|c|c|c|}
\hline \multicolumn{1}{|c|}{ Faktor Independen } & t-hitung & t-tabel & signifikan \\
\hline Penempatan Karyawan (X1) & 2,195 & 1,989 & 0,031 \\
\hline Pengembangan Karir (X2) & 5,817 & 1,989 & 0,000 \\
\hline
\end{tabular}

Sumber : data primer 
a. Variabel Penempatan Karyawan (X1)

Hasil pengujian dengan SPSS diperoleh variabel Penempatan Karyawan (X1) memiliki thitung lebih besar dari pada nilai $t_{\text {tabel }}$ yaitu 2,195 > 1,989. Dengan nilai signifikan penempatan karyawan (X1) yaitu 0,031 $<0,05$ sehingga dapat disimpulkan bahwa $\mathrm{H}_{0}$ ditolak dan $\mathrm{H}_{\mathrm{a}}$ diterima. Dengan demikian, maka hipotesis pertama dapat diterima.

b. Variabel Pengembangan Karir (X2)

Hasil pengujian dengan SPSS diperoleh variabel Pengembangan Karir (X2) memiliki $t_{\text {hitung }}$ lebih besar dari pada nilai $t_{\text {tabel }}$ yaitu 5,817 >1,989. Dengan nilai signifikan pengembangan karir $(\mathrm{X} 2)$ yaitu $0,000<0,05$ sehingga dapat disimpulkan bahwa $\mathrm{H}_{0}$ ditolak dan $\mathrm{H}_{\mathrm{a}}$ diterima. Dengan demikian, maka hipotesis kedua dapat diterima.

\section{Model Regresi II}

Derajat kebebasan (df) n-k-1 yaitu 85-2-1 = ( $\mathrm{n}$ merupakan jumlah responden dan $\mathrm{k}$ merupakan jumlah variabel independen), sehingga hasil yang diperoleh untuk $\mathrm{t}_{\text {tabel }}$ sebesar 1,989. Dari hasil olah data dapat disajikan pada tabel sebagai berikut ini:

\section{Tabel 4.23}

Uji Parsial Variabel Penempatan Karyawan (X1), Pengembangan Karir (X2) dan Motivasi Kerja (Z) terhadap Kepuasan $\operatorname{Kerja}(\mathbf{Y})$

\begin{tabular}{|l|c|c|c|}
\hline \multicolumn{1}{|c|}{ Faktor Independen } & t-hitung & t-tabel & signifikan \\
\hline Penempatan Karyawan (X1) & 1,421 & 1,989 & 0,159 \\
\hline Pengembangan Karir (X2) & -2.444 & 1,989 & 0,017 \\
\hline Motivasi Kerja Karyawan (Z) & 6.680 & 1,989 & 0,000 \\
\hline
\end{tabular}

Sumber : data primer

a) Variabel Penempatan Karyawan (X1)

Hasil pengujian dengan SPSS diperoleh variabel Penempatan Karyawan (X1) memiliki $t_{\text {hitung }}$ lebih kecil dari pada nilai $\mathrm{t}_{\text {tabel }}$ yaitu 1,421 < 1,989. Dengan nilai signifikannya yaitu 0,159 maka $\mathrm{H}_{0}$ diterima dan $\mathrm{H}_{\mathrm{a}}$ ditolak. Dengan demikian, maka hipotesis ketiga ditolak.

b) Variabel Pengembangan Karir (X2)

Hasil pengujian dengan SPSS diperoleh variabel Pengembangan Karir (X2) memiliki $t_{\text {hitung }}$ lebih kecil dari pada nilai $t_{\text {tabel }}$ yaitu $-2,444<1,989$. Dengan nilai signifikannya yaitu 0,017 maka $\mathrm{H}_{0}$ ditolak dan $\mathrm{H}_{\mathrm{a}}$ diterima. Dengan demikian, maka hipotesis keempat diterima.

c) Varibel Motivasi Kerja Karyawan (Z)

Hasil pengujian dengan SPSS diperoleh variabel Motivasi kerja karyawan $(Z)$ memiliki $t_{\text {hitung }}$ lebih besar dari pada nilai $t_{\text {tabel }}$ yaitu 6,680 > 1,989. Dengan nilai signifikan Motivasi kerja karyawan (Z) yaitu 0,000 maka $\mathrm{H}_{0}$ ditolak dan $\mathrm{H}_{\mathrm{a}}$ diterima. Dengan demikian, maka hipotesis kelima dapat diterima.

\subsubsection{Uji F}

\section{Model Regresi I}

Hasil perhitungan parameter model regresi secara bersama-sama diperoleh pada tabel berikut ini :

Hasil Pengujian Hipotesis Variabel Penempatan Karyawan (X1), Pengembangan Karir $\left(X_{2}\right)$ secara simultan terhadap Motivasi Kerja $(Z)$

\begin{tabular}{|rl|r|r|r|r|r|}
\hline \multicolumn{2}{|l|}{ Model } & \multicolumn{1}{|c|}{ ANOVA $^{\mathbf{a}}$} \\
& & $\begin{array}{l}\text { Sum of } \\
\text { Squares }\end{array}$ & df & Mean Square & F & Sig. \\
\hline \multirow{2}{*}{1} & Regression & 740.573 & 2 & 370.287 & 50.900 & $.000^{\mathrm{b}}$ \\
& Residual & 596.533 & 82 & 7.275 & & \\
& Total & 1337.106 & 84 & & & \\
\hline
\end{tabular}

a. Dependent Variable: Motivasi Kerja Karyawan (Z)

b. Predictors: (Constant), Pengembangan Karir (X2), Penempatan Karyawan (X1) 
Sumber : Data lampiran diolah SPSS versi 21

Uji F dimaksud untuk menguji ada tidaknya pengaruh variabel - variabel dependen secara simultan (bersama-sama). Hasil uji $\mathrm{F}$ dapat dilihat pada lampiran dengan hipotesis yang diajukan. Hasil perhitungan statistik menunjukkan nilai F-hitung $=50,900>$ F-tabel 3,11 dengan signifikansi $0,000<0,05$ maka Ho ditolak dan Ha diterima. Dengan demikian, model regresi tersebut sudah layak dan benar.

\section{Model Regresi II} ini:

Hasil perhitungan parameter model regresi secara bersama-sama diperoleh pada tabel berikut

Tabel 4.25

Hasil Pengujian Hipotesis Variabel Penempatan Karyawan (X1), Pengembangan Karir $\left(X_{2}\right)$ secara simultan terhadap Kepuasan Kerja (Y)

ANOVA $^{\mathrm{a}}$

\begin{tabular}{|rl|r|r|r|r|r|}
\hline \multicolumn{1}{|l|}{ Model } & \multicolumn{1}{c|}{$\begin{array}{l}\text { Sum of } \\
\text { Squares }\end{array}$} & df & Mean Square & F & Sig. \\
\hline \multirow{2}{*}{1} & Regression & 559.774 & 3 & 186.591 & 25.302 & $.000^{\mathrm{b}}$ \\
\cline { 3 - 5 } & Residual & 597.332 & 81 & 7.374 & & \\
& Total & 1157.106 & 84 & & & \\
\hline
\end{tabular}

a. Dependent Variable: Kepuasan Kerja (Y)

b. Predictors: (Constant), Motivasi Kerja Karyawan (Z), Penempatan Karyawan (X1),

Pengembangan Karir (X2)

Sumber : Data lampiran diolah SPSS versi 21

Uji $\mathrm{F}$ digunakan untuk menguji ada tidaknya pengaruh variabel - variabel dependen secara simultan (bersama-sama). Hasil uji $\mathrm{F}$ dapat dilihat pada lampiran dengan hipotesis yang diajukan. Hasil perhitungan statistik menunjukkan nilai F-hitung $=$ 25,302 $>$ F-tabel 3,11 dengan signifikansi $0,000<0,05$ maka Ho ditolak dan Ha diterima. Dengan demikian, model regresi tersebut sudah layak dan benar.

\subsection{Koefisien Determinasi (R)}

1. Model Regresi I

Hasil Koefisien Determinasi Variabel Penempatan Karyawan (X1), Pengembangan Karir $\left(X_{2}\right)$ terhadap Motivasi Kerja (Z)

Model Summary

\begin{tabular}{|l|r|r|r|r|}
\hline Model & \multicolumn{1}{|c|}{$\mathrm{R}$} & R Square & \multicolumn{1}{c|}{$\begin{array}{c}\text { Adjusted R } \\
\text { Square }\end{array}$} & $\begin{array}{c}\text { Std. Error of } \\
\text { the Estimate }\end{array}$ \\
\hline 1 & $.744^{\mathrm{a}}$ & .554 & .543 & 2.697 \\
\hline
\end{tabular}

a. Predictors: (Constant), Pengembangan Karir (X2),

Penempatan Karyawan (X1)

Sumber : Data lampiran diolah SPSS versi 21

Berdasarkan tabel diatas diperoleh nilai $\mathrm{R}$ Square sebesar 0,554 atau $55.4 \%$ hal ini menunjukkan bahwa persentase kontribusi dari variabel independen terhadap variabel dependen sebesar 0,554 atau 55.4\% Sedangkan sisanya sebesar 0,446 atau 44.6\% dipengaruhi oleh variabel lain diluar penelitian.

\subsection{Interpretasi Analisis Jalur}

Berdasarkan diagram jalur yang telah dirumuskan maka dapat disimpulkan pengaruh langsung dan tidak langsung sebagai berikut:

1. Pengaruh Penempatan Karyawan (X1) terhadap Kepuasan Kerja (Y) melalui Motivasi Kerja

(Z) sebagai variabel intervening 
a. $\quad$ Pengaruh langsung $=0,158$

b. Pengaruh tidak langsung melalui Motivasi Kerja $(Z)=0,219 * 0,798=0,174$

Maka dapat disimpulkan bahwa pengaruh tidak langsung penempatan karyawan (X1) terhadap Kepuasan Kerja (Y) melalui motivasi kerja (Z) lebih besar dibandingkan dengan pengaruh langsung penempatan karyawan (X1) terhadap kepuasan kerja (Y). Maka dengan begitu motivasi berpengaruh secara tidak langsung terhadap kepuasan kerja karena diintervening oleh motivasi kerja sebagai variabel Intervening. Dibuktikan dengan nilai Inderect effect > direct effect atau 0,174 > 0,158 pada Penempatan Karyawan, maka dapat dijelaskan bahwa motivasi kerja karyawan mampu berperan sebagai variabel intervening atau memediasi pengaruh penempatan karyawan terhadap kepuasan kerja melalui motivasi kerja karyawan sebagai variabel intervening.

2. Pengaruh Pengembangan Karir (X2) terhadap Kepuasan Kerja (Y) melalui Motivasi Kerja (Z) sebagai variabel intervening

a. Pengaruh langsung $=-0,313$

b. Pengaruh tidak langsung melalui Motivasi kerja $(Z)=0,579 * 0,798$ $=0,462$

Maka dapat disimpulkan bahwa pengaruh tidak langsung pengembangan karir (X2) terhadap Kepuasan Kerja (Y) melalui motivasi kerja (Z) lebih besar dibandingkan dengan pengaruh langsung pengembangan karir (X2) terhadap kepuasan kerja (Y). Maka dengan begitu motivasi berpengaruh secara tidak langsung terhadap kepuasan kerja karena diintervening oleh motivasi kerja sebagai variabel Intervening. Dibuktikan dengan nilai Inderect effect $>$ direct effect atau 0,462 > (-0,313) pada pengembangan karir, maka dapat dijelaskan bahwa motivasi kerja karyawan mampu berperan sebagai variabel intervening atau memediasi pengaruh pengembangan karir terhadap kepuasan kerja melalui motivasi kerja karyawan sebagai variabel intervening.

\section{Pembahasan dan Hasil Penelitian}

Berdasarkan hasil penelitian yang telah dilakukan, maka penulis dapat mengimplikasikan hal-hal sebagai berikut:

\section{a. Pengaruh Penempatan Karyawan terhadap Motivasi Kerja}

Hasil dari penelitian menemukan bahwa Penempatan Karyawan (X1) berpengaruh positif dan signifikan terhadap Motivasi Kerja (Z). Dibuktikan dengan nilai sig $(0,031)<(0,05)$. Berdasarkan hasil yang diperoleh maka Ho ditolak dan Ha diterima untuk variabel penempatan karyawan. Dengan demikian, maka hipotesis diterima. Maka dapat disimpulkan bahwa secara parsial variabel Penempatan Karyawan (X1) berpengaruh positif dan signifikan terhadap Motivasi Kerja (Z). Hasil penelitian ini sejalan dengan Penelitian yang dilakukan oleh (Miiftakhu Rokhman Nur Ask Shidiq, Nur Ash Shidiq, M., 2019) yang menyatakan bahwa penempatan karyawan berpengaruh positif dan signifikan terhadap motivasi kerja karyawan.

\section{b. Pengaruh Pengembangan Karir terhadap Motivasi Kerja}

Hasil dari penelitian menemukan bahwa Pengembangan Karir (X2) berpengaruh positif dan signifikan terhadap Motivasi Kerja $(\mathrm{Z})$. Dibuktikan dengan nilai sig $(0,000)<(0,05)$. Berdasarkan hasil yang diperoleh maka Ho ditolak dan Ha diterima untuk variabel Pengembangan karir. Dengan demikian, maka hipotesis diterima. Maka dapat disimpulkan bahwa secara parsial variabel Pengembangan Karir (X2) berpengaruh positif dan signifikan terhadap Motivasi Kerja Karyawan (Z). Penelitian ini sesuai dengan penelitian sebelumnya yang dilakukan oleh (Lisdiani \& Ngatno, 2017) yang menyatakan bahwa Pengembangan karir berpengaruh positif dan signifikan terhadap Motivasi kerja.

\section{c. Pengaruh Penempatan Karyawan terhadap Kepuasan Kerja}

Hasil dari penelitian menemukan bahwa Penempatan Karyawan (X1) berpengaruh tidak signifikan terhadap Kepuasan Kerja (Y). Dibuktikan dengan nilai sig $(0,159)>(0,05)$. Berdasarkan hasil yang diperoleh maka Ho diterima dan Ha ditolak untuk variabel Penempatan karyawan. Dengan demikian, maka hipotesis ditolak. Maka dapat disimpulkan bahwa secara parsial variabel Penempatan Karyawan (X1) berpengaruh tidak signifikan terhadap Kepuasan Kerja (Y). Penelitian ini sesuai dengan penelitian sebelumnya yang dilakukan oleh (Lisnawati et al., 2017) yang menyatakan bahwa Penempatan Karyawan sacara parsial berpengaruh tidak signifikan terhadap Kepuasan Kerja 


\section{d. Pengaruh Pengembangan Karir terhadap Kepuasan Kerja}

Hasil dari penelitian menemukan bahwa Pengembangan Karir (X2) berpengaruh positif dan signifikan terhadap Kepuasan Kerja (Y). Dibuktikan dengan nilai sig $(0,017)<(0,05)$. Berdasarkan hasil yang diperoleh maka Ho ditolak dan Ha diterima untuk variabel Pengembangan karir. Dengan demikian, maka hipotesis diterima. Maka dapat disimpulkan bahwa secara parsial variabel Pengembangan Karir (X2) berpengaruh positif dan signifikan terhadap Kepuasan Kerja (Y). Penelitian ini sesuai dengan penelitian sebelumnya yang dilakukan oleh (Bahri \& Chairatun Nisa, 2017) yang menyatakan bahwa Pengembangan Karir sacara parsial memiliki pengaruh yang signifikan terhadap Kepuasan Kerja

\section{e. Pengaruh Motivasi Kerja terhadap Kepuasan Kerja}

Hasil dari penelitian menemukan bahwa Motivasi Kerja (Z) berpengaruh Positif dan Signifikan terhadap Kepuasan Kerja (Y). Dibuktikan dengan nilai sig $(0,000)<(0,05)$. Berdasarkan hasil yang diperoleh maka Ho ditolak dan Ha diterima untuk variabel Motivasi kerja. Dengan demikian, maka hipotesis diterima. Maka dapat disimpulkan bahwa secara parsial variabel Motivasi Kerja (Z) berpengaruh positif dan signifikan terhadap Kepuasan Kerja (Y). Hasil penelitian ini sejalan dengan Penelitian yang dilakukan oleh (Purwanto, 2019) yang menyatakan bahwa Motivasi Kerja sacara parsial memiliki pengaruh yang signifikan terhadap Kepuasan Kerja.

\section{f. Pengaruh Langsung dan Tidak Langsung Penempatan Karyawan Terhadap Kepuasan Kerja}

Hasil dari penelitian menemukan bahwa Penempatan Karyawan (X1) berpengaruh positif dan signifikan secara tidak langsung terhadap Kepuasan Kerja (Y) melalui Motivasi Kerja Karyawan (Z) sebagai variabel Intervening. Dibuktikan dengan nilai Inderect effect > direct effect atau 0,174 > 0,158 pada penempatan karyawan, maka dapat disimpulkan bahwa Motivasi Kerja Karyawan (Z) mampu berperan sebagai variabel intervening atau memediasi pengaruh Penempatan Karyawan (X1) terhadap Kepuasan Kerja (Y) melalui Motivasi Kerja Karyawan (Z) sebagai variabel intervening.

\section{g. Pengaruh Langsung dan Tidak Langsung Pengembangan Karir Terhadap Kepuasan Karyawan}

Hasil dari penelitian menemukan bahwa Pengembangan Karir (X2) berpengaruh positif dan signifikan secara tidak langsung terhadap Kepuasan Kerja (Y) melalui Motivasi Kerja Karyawan (Z) sebagai variabel Intervening. Dibuktikan dengan nilai Inderect effect $>$ direct effect 0,462 > (-0,313) pada Pengembangan karir, maka dapat disimpulkan bahwa Motivasi Kerja Karyawan (Z) mampu berperan sebagai variabel intervening atau memediasi pengaruh Pengembangan Karir (X2) terhadap Kepuasan Kerja (Y) melalui Motivasi Kerja Karyawan (Z) sebagai variabel intervening.

\section{Kesimpulan}

Dari pembahasan pada bab-bab sebelumnya, maka dapat ditarik beberapa kesimpulan sebagai berikut

1. Pengaruh Penempatan Karyawan (X1) terhadap Motivasi Kerja (Z). Dapat diperoleh nilai signifikan sebesar $0,031<0,05$ sehingga Penempatan Karyawan berpengaruh positif dan signifikan terhadap Motivasi Kerja Karyawan.

2. Pengaruh Pengembangan Karir (X2) terhadap Motivasi Kerja (Z).

Dapat diperoleh nilai signifikan sebesar $0,000<0,05$ sehingga Pengembangan Karir berpengaruh positif dan signifikan terhadap Motivasi Kerja.

3. Pengaruh Penempatan Karyawan (X1) terhadap Kepuasan Kerja (Y).

Dari pembahasan diatas dapat diperoleh nilai signifikan sebesar 0,159>0,05 sehingga Penempatan Karyawan berpengaruh tidak signifikan terhadap Kepuasan Kerja.

4. Pengaruh Pengembangan Karir (X2) terhadap Kepuasan Kerja (Y).

Dapat diperoleh nilai signifikan sebesar $0,017<0,05$ sehingga Pengembangan Karir berpengaruh positif dan signifikan terhadap Kepuasan Kerja

5. Pengaruh Motivasi Kerja Karyawan (Z) terhadap Kepuasan Kerja (Y).

Dapat diperoleh nilai signifikan sebesar $0,000<0,05$ sehingga Motivasi Kerja Karyawan berpengaruh positif dan signifikan terhadap Kepuasan Kerja.

6. Pengaruh Langsung dan tidak Langsung penempatan karyawan (X1) terhadap Kepuasan Kerja (Y). 
Dapat diperoleh nilai Inderect effect $>$ direct effect atau 0,174 > 0,158 sehingga Penempatan Karyawan berpengaruh positif dan signifikan secara tidak langsung terhadap Kepuasan Kerja melalui Motivasi Kerja Karyawan sebagai variabel intervening.

7. Pengaruh Langsung dan tidak langsung Pengembangan Karir (X2) terhadap Kepuasan Kerja (Y).

Dapat diperoleh nilai Inderect effect > direct effect atau 0,462 > (-0,313) sehingga Pengembangan Karir berpengaruh positif dan signifikan secara tidak langsung terhadap Kepuasan Kerja melalui Motivasi Kerja Karyawan sebagai variabel intervening.

\section{DAFTAR PUSTAKA}

Bahri, S., \& Chairatun Nisa, Y. (2017). Pengaruh Pengembangan Karir Dan Motivasi Kerja Terhadap Kepuasan Kerja Karyawan Pada PT. Bank Sulutgo Kantor Pusat Manado. Jurnal Ilmiah Manajemen Dan Bisnis. Https://Doi.Org/10.30596/Jimb.V18i1.1395

Diansyah, \& Saepul, T. (2017). Pengaruh Pelatihan Dan Kompensasi Terhadap Kinerja Karyawan Dengan Motivasi Sebagai Variabel Intervening Pada Mikro Laju Cluster Jakarta 2 PT. Bank CIMB Niaga TBK. Jurnal Online Internasional \& Nasional.

Hasibuan, M. S. P. (2019). Manajemen Sumber Daya Manusia (Cetakan 18). PT Bumi Aksara.

Lisdiani, V., \& Ngatno, N. (2017). Pengaruh Pengembangan Karir Terhadap Kepuasan Kerja Karyawan Melalui Motivasi Kerja Sebagai Variabel Intervening (Studi Kasus Pada Hotel Grasia Semarang). Jurnal Ilmu Administrasi Bisnis S1 Undip, 6(4), 105-112.

Lisnawati, Musnadi, S., \& Putra, T. R. I. (2017). Pengaruh Kompensasi Dan Penempatan Terhadap Kepuasan Kerja Serta Dampaknya Terhadap Kinerja Organisasi Pada Badan Kepegawaian, Pendidikan Dan Pelatihan (Bkpp) Aceh. Jurnal Perspektif Manajemen Dan Perbankan, 8(3), 118.

Lukiyana. (2017). Pengaruh Rekrutmen Dan Pengalaman Kerja Terhadap Prestasi Kerja Karyawan Dengan Penempatan Kerja Sebagai Variabel Intervening. Jurnal Online Internasional \& Nasional.

Mangkunegara, A. P. (2017). Manajemen Sumber Daya Manusia Perusahaan (Susan Sandiasih (Ed.); Cetakan 14). PT REMAJA ROSDAKARYA.

Miiftakhu Rokhman Nur Ask Shidiq, Nur Ash Shidiq, M., A. 2019. (2019). Pengaruh Pelatihan Dan Ketepatan Penempatan Kerja Terhadap Kinerja Dengan Motivasi Sebagai Variabel Intervening (Studi Pada Karyawan PKP-PK PT.Angkasa Pura II Persero). Journal Of Management, 1(1).

Purwanto, H. (2019). PENGARUH BUDAYA ORGANISASI DAN MOTIVASI KERJA TERHADAP KEPUASAN KERJA DALAM MENINGKATKAN KINERJA KARYAWAN (STUDI KASUS PT PLN (PERSERO) DISTRIBUSI JAKARTA RAYA). JEBA (Journal Of Economics And Business Aseanomics), 3(1), 60-80. Https://Doi.Org/10.33476/Jeba.V3i1.742

Siagian, S. P. (2018). Manajemen Sumber Daya Manusia (1st Ed.). PT Bumi Aksara.

Sutrisno, E. (2019). Manajemen Sumber Daya Manusia (1st Ed.). PRENADAMEDIA GROUP (Divisi Kencana).

Wahyuni, D., \& Pase, A. K. (2019). THE EFFECT OF POSITION AND WORK PLACEMENT PROMOTION IN REGIONALAND EDUCATION EMPLOYEE AND TRAINING AGENCY, TANJUNGBALAI CITY. Jurnal International Conference University Of Asahan2019, 577583. 